Paideusis

\title{
A Deweyan Reaction to "Ed Schools"
}

\section{Brian Hendley}

Volume 4, Number 1, 1990

URI: https://id.erudit.org/iderudit/1073391ar

DOI: https://doi.org/10.7202/1073391ar

See table of contents

Publisher(s)

Canadian Philosophy of Education Society

ISSN

0838-4517 (print)

1916-0348 (digital)

Explore this journal

Cite this article

Hendley, B. (1990). A Deweyan Reaction to "Ed Schools". Paideusis, 4(1), 19-24.

https://doi.org/10.7202/1073391ar

(C) Brian Hendley, 1990

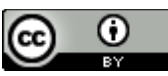

This document is protected by copyright law. Use of the services of Erudit (including reproduction) is subject to its terms and conditions, which can be viewed online.

https://apropos.erudit.org/en/users/policy-on-use/
This article is disseminated and preserved by Érudit.

Érudit is a non-profit inter-university consortium of the Université de Montréal, Université Laval, and the Université du Québec à Montréal. Its mission is to promote and disseminate research.

https://www.erudit.org/en/ 


\section{A Deweyan Reaction to "Ed Schools"}

\section{Brian Hendley}

\section{University of Waterloo}

Schools of education have become "like the mammals in the age of the dinosaurs - small, quiet, nocturnal omnivores, coming out after 4:10 pm to forage and ruffle their fur a little, reflecting a few rays of the vanishing sun." 1 This graphic description of the perilous survival of today's "ed schools" comes from a new book of that title by Geraldine Clifford and James Guthrie. The book is written in the spirit of other recent critiques of teacher education in America, such as the Carnegie Report and the Report of the Holmes Group, as well as the recent position paper on teacher education in Ontario prepared by Michael Fullan and F. Michael Connelly. ${ }^{2}$ After tracing the not always edifying history of U.S. schools of education since their founding at the beginning of this century, and considering case studies of what went wrong at some of the most famous (Stanford, Michigan, Chicago, Berkeley, Teachers College, and Harvard), Clifford and Guthrie conclude with some advice on how. "ed schools" can move beyond the mistakes of the past, continue to exist and even begin to flourish by properly functioning as "places of action and places of analysis" (323 ff.).

The main problem, as they see it, is that by trying unsuccessfully to serve two different masters, the faculty at schools of education have become "marginal men, aliens in their own worlds .. [who] have seldom succeeded in satisfying the scholarly norms of their campus letters and science colleagues, and ... are simultaneously estranged from their practising professional peers" (3). If they attempt to be more scholarly in their approach to education, they are dismissed by the teaching profession as being irrelevant to the daily concerns of the teacher in the classroom; and yet when they do try to address the practical problems to be faced in the operation of public schools, they are disparaged as unscholarly by their campus colleagues. The solution that Clifford and Guthrie propose is for schools of education to stop trying to please both camps and concentrate on their proper task, the educating of practitioners (350). They should "face their historic failures boldly" and "divest themselves of false pretences to being miniature models of social science institutes or liberal arts departments" by acknowledging their need to become professional schools and aligning themselves with "their natural constituency of practising educators ..." (366).

Schools of education should evolve their own professional amalgam, paying heed to the productive connection to the field that exists in many law schools, the emphasis on the practical application of research in medical schools, the high standards for preparing graduates characteristic of engineering schools, and the programmatic research in field-generated inquiries characteristic of schools of agriculture (353-354). The exchange of ideas across subspecialties within schools of education should continue to be encouraged, but such systematic inquiry should always be integrated into the training programmes, because "knowledge must be tested by practitioners" (364). This move toward increased professionalization will by no means be an easy task, the authors warn, because the public perceives education as a profession which is 
technologically weak; and the popular belief that almost anyone can do it, reinforces the low status of the field (328). The authors reject previous strategies for survival, such as joint faculty appointments ("interdisciplinary appeasement"), academic intensification (Ph.Ds in education), and "the route of social science legitimacy" (appointing social scientists as faculty members). Rather than pursue such "dysfunctional coping strategies," they would have schools of education identify a correct professional purpose which will strengthen American education" (341).

While recounting the "pain and discouragement of seeking intra-campus collaboration in educational research and teacher preparation," Clifford and Guthrie argue that schools of education do not require such campus regard in the first place; rather, they need "sufficient professional and public regard to survive" (347-348). Their major mission should be "the enhancement of education through the preparation of educators, the study of the educative process, and the study of schooling as a social institution." In order to accomplish this, they must take "the profession of education, not academia as their main point of reference" (349). Although firm in their conviction that schools of education must rise above hostile university environments and focus attention on the profession of education, Clifford and Guthrie are not very forthcoming on precisely how this is to be done.

They do take pains to point out that "the administrative strategy of forming laboratory schools to get scholars involved with schools failed most of the time - at Chicago, Berkeley, Michigan, and elsewhere" (112). Many campus schools fell victim to a confusion in functions, trying to design, evaluate, and demonstrate new instructional approaches so as to impress visitors from other schools and the public at large, while at the same time, and in the same setting, attempting to show preservice teachers the best ways to teach (113). Faculty began to turn elsewhere for research purposes and the supervision of practice teaching became "the lowest-status element in teacher education" (115). Many such schools eventually changed from being truly experimental schools to the more comfortable role of operating as small on-campus schools that offered a preparatory education to a student body that was fifty per cent faculty offspring (241). In some cases, high tuition and the steadily changing social and racial composition of neighbourhoods sealed the fate of university elementary schools. Even the well-established university practice schools were challenged on the grounds that prospective teachers would be better trained in representative public schools (274). Educational researchers came to ignore classrooms altogether, whether in laboratory or regular schools, and "questionnaires, surveys, studies in campus educational clinics, psychology classrooms, and libraries made education school itself the locus of most educational research ...." (120).

Thus, it would seem that Dewey's hope that the education of teachers at universities would serve as an occasion for the efficacious interaction of theory and practice was ill-founded. Clifford and Guthrie state unequivocally that "No American university has successfully melded first-rate scholarship in education with a continuing and constructive engagement with the problem of the schools" (363). They argue that the time has come for schools of education to break out of this unsuccessful partnership with the rest of the university and no longer to try to best the disciplinary departments at their own game. Instead, they should change their focus from within to without and concentrate on be- 
coming truly professional schools of education. Dewey, among others, is criticized for promoting the misleading ideal that schools of education should first and foremost be a vital part of the continuum of university education. On the contrary, "ed schools" should be autonomous and professional, serving the needs of educational practitioners, seeking public rather than campus regard. Before accepting this conclusion, let us briefly re-examine Dewey's views on teacher education in order to see whether anything can be salvaged from what seems to be an untenable situation.

Dewey distinguished between the skills and techniques of good teaching (what we might call the know-how, or tools of the trade) and the subject-matter or course content to be taught (the knowledge-that something is the case, the facts, information, values and ideas to be conveyed to the student). The former were acquired through training and apprenticeship. By observing a master teacher on the job and then being given a certain amount of responsibility for selecting and presenting the material on the curriculum, the student-teacher would gain some proficiency in the art of teaching. Mastery of subject-matter, on the other hand, involves being initiated into the working standards of a tradition." The would-be teacher should become "fairly saturated with his subject-matter," said Dewey; but even this initiation into scholarship should not be to the exclusion of method. On the academic side of professional training, the student would be trained in the higher levels of intellectual method, and thereby initiated into scientific method, the method of the mind itself. ${ }^{4}$ While studying history, geography, or English, the prospective teacher also learns how to think in a disciplined fashion, and thus will be able to maintain a high standard for thinking in his or her own classroom. There is simply no avoiding the necessity for the teacher to be a master of the subject being taught.

But something more than subject-matter - methods of thinking and techniques of teaching - is needed. A teacher should also be aware of different theories of education. This includes knowledge of the history of schools as social and political institutions, a study of various systems of pedagogy that have emerged, and discussion of past and present ideas in psychology and sociology in their bearings on the curriculum and on methods of education. 5 All of this was part of the development of a "scientific" approach to education in the sense of seeking a systematic increase of intelligent control and understanding of the process. Such a theory of education began and ended in practice. The practical situation at hand supplied many of the problems to be dealt with as well as the ultimate test of working hypotheses designed to solve the problems encountered. Theory is in the end "the most practical of all things," said Dewey, because it widens our range of attention, enables us to see more relations and possibilities, and enriches our ability to judge. ${ }^{6}$

It was such theories of education that Dewey was so eager to bring to the test in his Laboratory School. Dewey's School was never intended to be a school for practice-teaching as such; rather, it was set up with the avowed aim of testing and demonstrating theories and principles of education. For this reason, Dewey specified that his school was not a training ground for rank and file teachers but was meant for teachers in normal schools and training schools, professors of pedagogy, superintendents and principals of schools in large cities. They had already served an apprenticeship, learned the elements of theory, and attained mastery of their subject-matter ("Pedagogy", 281). Perhaps this is 
where some schools of education have gone wrong in their attempts to follow Dewey's ideas on teacher education. He never portrayed his Laboratory School as a model of the kind of place where practising teachers picked up the tools of the trade. Nor did he see its primary role to be that of providing faculty with the opportunity to study children at first hand as a kind of captive research sample. It was intended to accomplish the very thing that Clifford and Guthrie have advocated: the education of practitioners. ${ }^{7}$

Dewey sought to produce what have recently been called "reflective practitioners," those who can achieve reflection-in-action by being "attentive to patterns of phenomena, skilled at describing what ... [they] observe, inclined to put forward bold and sometimes radically simplified models of experience, and ingenious in devising tests of them compatible with the constraints of an action setting." 8 Such practitioners are indeed knowledgeable and skilled, but they are also creative, imaginative, and critical thinkers who can see the larger picture, adapt to changing circumstances, combine thought and action in challenging new ways. For Dewey, the value of the science, the history and philosophy of education for the would-be teacher "resides in the enlightenment and guidance it supplies to observation and judgment of actual situations as they arise" (Science, 31). The reason he thought that it was "intellectually necessary and practically fitting" to have a laboratory school connected to his Department of Pedagogy, was that such an institutional setting for reflective educational practice provided "the intellectual method and material of good workmanship" ("Theory", 250).

A large part of the method and material of good workmanship in teaching involves this ability to reflect about and within practice. This requires more than mastery of one's subject or exposure to the latest techniques; the would-be teacher should also be able to theorize in a more general way about the educational process itself. Since Dewey felt strongly that the last word had not been said about educational aims, methods, and subject-matter, the Laboratory School provided a good opportunity for testing, revising, and clarifying various theories of education. There was to be no dogmatic presentation of any single view as the correct one. The test of classroom practice might indicate obscurity of thought as well as inaccuracy or falsity of the theory. Theories were to be worked over or "reconstructed" ' and not simply memorized or dismissed.

One might argue that this never actually happened and that the School functioned mainly as an outlet for the promulgation of Dewey's pet educational theories, come what may. In fact, he later admitted that "the research persons connected with the school system may be too close to the practical problems and the university professor too far away from them to secure the best results" (Science, 43). The point worth noting is the underlying rationale, which was to bring practical experience and theoretical instruction to bear on day-to-day problems of classroom teaching in order to facilitate the growth of theory and increase the intelligent control of practice. I fail to see how we can educate teachers properly without giving due emphasis to both theory and practice in this sense, without getting them to reflect upon what they are doing and why, while also giving them a chance to try to do it.

Perhaps the biggest failure in the dismal history of "ed schools" that Clifford and Guthrie trace is that so few philosophers have heeded Dewey's call to take education seriously and see it as a test of their views on the good life and 
how it is to be achieved. Too many have remained in the closeted seclusion that Dewey chided against. Very few theories of the good life have been proposed with a view to determining their educational implications. A subsidiary failure to that of the theoreticians might well be the self-imposed isolation of many faculty at schools of education who see themselves as poor cousins of their colleagues in mainstream disciplines. No doubt, some of this feeling of being under-appreciated is legitimate, but how many overtures have been made to the scholarly world from the ranks of those who teach teachers? To be largely ignored or treated with indifference may make conversation more difficult, but it certainly does not preclude continuing to try to begin one.

Dewey issued a broader call to action by reminding us of how much is really at stake in education. It is all too easy to forget, he said, that "in every school-building in the land a struggle is also being waged against all that hems in and distorts human life." It is a struggle that is often slow and imperceptible, but extremely important, nonetheless, since it concerns the most fundamental issues of human freedom and the pushing back of the boundaries that restrict human life. He urged academics as well as practitioners to join in this, "the greatest of all battles in the cause of human liberation, to the end that all human beings may lead the life that is alone worthy of being entilled wholly human." If we cannot join forces on this most crucial project, bringing our scholarly expertise and practical experience to bear on the most basic of questions on the kind of lives we want humans to live, while setting aside our academic competitiveness and intra-campus posturings for prestige, then we shall all have failed as educators, and, more importantly, as human beings. 


\section{Notes}

${ }^{1}$ Geraldine Joncich Clifford and James W. Guthrie, Ed School (Chicago: University of Chicago Press, 1988), 325. Hereafter cited in the text.

${ }^{2}$ A Nation Prepared: Teachers for the Twenty-First Century. (New York: Carnegie Forum on Education and the Economy, May, 1986); Tomorrow's Teachers: A Report of the Holmes Group (East Lansing, Michigan: Holmes Group, 1986), Michael Fullan and F. Michael Connelly, Teacher Education in Ontario: Current Practice and Options for the Future (Ontario Ministry of Education, January, 1987). For a good collection of responses to A Report of the Holmes Group, see Jonas F. Soltis (ed.), Reforming Teacher Education: The Impact of the Holmes Group Report (New York: Teachers College Press, 1987). This collection has been reviewed by Delbert Long in Educational Studies, 19(Fall/Winter), 1988, 321-327.

3John Dewey, "Individuality and Experience" (1926) in Jo Ann Boyston (ed.), Later Works 2:57 (Carbondale, Illinois: Southern Illinois University Press, 1984).

4John Dewey, "The Relation of Theory to Practice in Education" (1904) in Jo Ann Boyston (ed.), Middle Works 3:256 (Carbondale, Illinois: Southern Illinois University Press, 1977), 263. Hereafter cited in the text as "Theory".

5John Dewey, "Pedagogy as a University Discipline" (1896) in Jo Ann Boyston (ed.), Early Works 5:285-288 (Carbondale, Illinois: Southern Illinois University Press, 1972). Hereafter cited in the text as "Pedagogy".

6John Dewey, The Sources of a Science of Education (New York: Liveright, 1929), 17-21. Hereafter cited in the text as Science.

'For more on Dewey's School, see my Dewey, Russell, Whitehead: Philosophers as Educators (Carbondale, Illinois: Southern Illinois University Press, 1986).

${ }^{8}$ Donald A. Schon, Educating the Reflective Practitioner (San Francisco: Jossey-Bass, 1987), 322. Cf. also his The Reflective Practitioner (New York: Basic Books, 1983.) Also of interest is Harold Entwistle, "The Relationship between Educational Theory and Practice: A New Look," in Philosophy of Education, Introductory Readings (Calgary, Alberta: Detselig Enterprises Lid., 1988), edited William Hare and John P. Portelli, 23-32.

9John Dewey, "Philosophy and Education" (1930), in Jo Ann Boyston (ed.), Later Works 5:298 (Carbondale, Illinois: Southern Illinois University Press, 1984). 